\title{
Evolving conceptions of the role of large dams in social-ecological resilience
} Mia A. Hammersley ${ }^{1}$, Christopher Scott $^{2,3}$ and $\underline{\text { Randy Gimblett }}^{4}$

\begin{abstract}
Rivers and riparian ecosystems have historically provided a range of beneficial goods and services to human societies. However, floodplains have also posed risks to the humans that came to rely upon them. Although riparian areas are among the most resource-rich and biodiverse ecosystems, they are also some of the most disturbed by human activity. Today, social and economic needs for water diverted off-stream are often pitted against the flow of water needed to maintain crucial instream ecological functions. The construction of dams has been a widely implemented method to control rivers for human purposes, particularly in the western United States. However, there is a growing movement to decommission dams, as stakeholders begin to recognize the ultimate value of restoring ecosystem services, including cultural ecosystem services; indeed, their restoration may be necessary to ensure lasting systemic resilience. Broader questions of dam decommissioning in the United States are receiving increasing attention by scholars and practitioners alike. In this paper, we adapt and apply seminal concepts from the adaptive cycle framework and cultural ecosystem services, particularly for Native Nations, and thereby assess the unfolding case of decommissioning and restoration on the Elwha River in northwest Washington State. The empirical evidence indicates that dam removal coincided with scalar and temporal alignment of multiple adaptive cycles and contributed to both short and long-term resilience. Further, the Elwha case represents an extremely important precedent in the evolution of river management practices, in which stakeholder-based collaborative governance incorporated knowledge coproduction and regulatory maneuvering to successfully overcome obstacles inherent in both dam decommissioning and subsequent restoration. We conclude by reflecting on lessons of broader relevance beyond the specific case of the Elwha.
\end{abstract}

Key Words: adaptive cycle; cultural ecosystem services; dam decommissioning; knowledge coproduction; Native Nations; riparian restoration; salmon

\section{INTRODUCTION}

Dams have historically been constructed as humans attempted to address the unpredictable flow regimes of river ecosystems in order to secure and store a reliable supply of water for a range of uses, prevent unregulated flooding events, produce mechanical and electrical power, and even create new markets for recreation activities (The World Commission on Dams 2000). Many water managers as well as public and private decision makers consider dams as a key tool to enhance societal resilience in the face of water demand and supply uncertainty (Department of the Interior 2007). Dam construction modified entire landscapes, both on- and off-river, in effect creating novel ecosystems and complex human economies (Fiege 1999). However, in an age of growing environmental awareness, the recognition of the rights of the displaced, particularly Native Nations (Dallman et al. 2013), and widespread modification of watersheds, dams are increasingly seen as a rigid impediment to systemic resilience. Dam decommissioning is becoming an increasingly accepted method of river restoration as the preservation and restoration of river and riparian ecosystems becomes increasingly important to strengthen lasting social-ecological resilience.

In social-ecological systems (SES) terms, the Elwha River encompasses more than just the water body; the river is also its flow regime, watershed, human and ecological processes, as well as disturbance features and dynamics. Following this expanded understanding of SES resilience (Folke 2016), damming a river may fundamentally alter the flow regime, and critically for the cases we consider, limit historical and cultural human values as well as riparian ecosystem processes. The dynamics of the Elwha River watershed as an SES can be explained by applying
Gunderson and Holling's (2002) adaptive cycle framework to examine the Elwha River with special emphasis on the decommissioning of the Elwha and Glines Canyon Dams; we apply this analysis here in order to highlight the innovative insights that this case provides as a successful river restoration initiative. In addition to the return of several salmon species to upstream areas of the Elwha watershed in numbers that have not been seen since before the dams were constructed, scientists also expect that the dam removals will positively impact the hydromorphology, biology, and general ecological processes in the Elwha ecosystem (McHenry and Pess 2008). In turn, the Lower Elwha Klallam Tribe view the dam removals as a revival of their cultural heritage and traditional way of life (Guarino 2013).

River basins are SES, or "social-hydrological systems," providing water for both human needs and ecosystem functions, which are inherently linked (Scott et al. 2014). Rivers around the world have been influenced by human infrastructure including dams, weirs, barrages, diversions, tunnels, aqueducts, bridges, etc., that lead to shifts in the natural flow regime (Poff et al. 1997) and loss of biodiversity and ecosystem services. Ecosystem services at risk may include cultural ecosystem services (Alexander et al. 2016). Cultural services are those nonmaterial benefits obtained from ecosystems that are based on human values, e.g., aesthetic and recreational experiences, cultural heritage including spiritual values, and sense of place (Peters et al. 2013). Where Native Nations are concerned, the management of river ecosystems for extractive economic gain and related human uses of water may directly conflict with cultural ecosystem services such as spiritual connection with sacred spaces and connection to ancestral lands

${ }^{1}$ James E. Rogers College of Law, University of Arizona, ${ }^{2}$ Udall Center for Studies in Public Policy, University of Arizona, ${ }^{3}$ School of Geography \& Development, University of Arizona, ${ }^{4}$ School of Natural Resources and the Environment, University of Arizona 
and traditions (Dallman et al. 2013). In the context of whitewater recreation, cultural ecosystem services such as increasing human use as seen on the White Salmon River in Washington State is perceived to be threatening the recovery of the river as it continues to rewild postdam removal (Gimblett et al. 2017). Failing to holistically address threats to a river and ensuing impacts on ecosystem services may decrease the resilience of the entire SES (Scott et al. 2014).

\section{Dams and decommissioning}

Approximately $85 \%$ of dams in the United States will reach the "end of their operational lives by 2020" (Doyle et al. 2003:453). As more dams age, the benefits of removing them before they fail may outweigh the costs in order to restore the river ecosystems that they have altered (Whitelaw and Macmullan 2002). Dams have many negative effects on river and riparian ecosystems, including habitat fragmentation, decreases in species richness, alteration of sediment dynamics and water temperature, and changes in geomorphology, all related to disruption of the natural flow regime (Doyle et al. 2003, Poff et al. 1997). However, the emergence of dam removal as an increasingly accepted method of river restoration exemplifies how the perception of dams and their effects on the environment have changed since they were originally constructed (Stanley and Doyle 2003). Communities are beginning to understand the full extent to which river and riparian ecosystems provide beneficial ecosystem services to society; the removal of old, obsolete, or ecologically harmful dams can provide a greater benefit than allowing them to remain (Pejchar and Warner 2001). However, the idea of dam removal is still often met with resistance; local communities may oppose removal of a dam because of its significance to regional history, identity, or landscape aesthetic (Fox et al. 2016, Magilligan et al. 2017).

River and riparian ecosystems continue to be threatened by a diverse array of disturbances, among them both proximate drivers (including flow-regime controls, instream construction, watershed road-access) and distal processes (population growth, changes in land use, and climate change). Today, SES are being subjected to disturbance more quickly than they can adapt (Walker and Salt 2012). This is particularly true for river SES, which represent crucial points of intersection between human and ecosystem needs and consequently, their shared vulnerabilities. Although riparian areas are among the most resource rich and biodiverse ecosystems, they are also among the most disturbed by human activity (Nilsson and Svedmark 2002). In the Northwest U.S. and other locations for example, salmon are particularly vulnerable to streamflow alterations and barriers to movement caused by damming rivers (Harnish et al. 2014, Fox et al. 2016). In the face of these growing disturbances, ensuring the resilience of river SES may also ensure their long-term survival. In order to accomplish this, it is necessary to reestablish flow regimes that can successfully accommodate ecological processes as well as ecosystem services to meet human needs (Richter et al. 2006).

\section{Panarchy of river social-ecological systems}

Gunderson and Holling (2002) describe this age of increased disturbances under the Panarchy framework, which describes slow, rapid, and cumulative changes occurring across multiple scales in complex SES. They outline four phases of the adaptive cycle, represented in the model of an infinity loop (a reposing figure eight, see Fig. 1). The phases consist of rapid growth $(r)$, conservation $(k)$, release $(\Omega)$, and renewal $(\alpha)$. In the context of river SESs, we understand and apply the phases of the adaptive cycle as the sequence of disturbances following decommissioning of the dammed condition, which is a rigidity-trap (See Table 1).

Fig. 1. The adaptive cycle. Gunderson and Holling (2002).

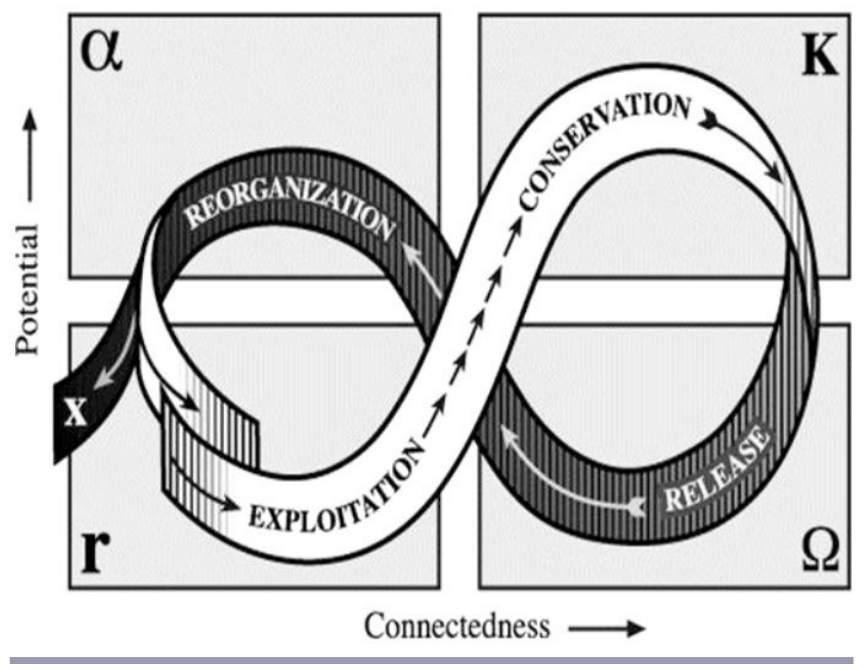

Table 1. Dam decommissioning in relation to phases of river-SES adaptive cycle.

\begin{tabular}{|c|c|c|c|}
\hline & Process & $\begin{array}{l}\text { Ecological } \\
\text { subsystem }\end{array}$ & Social subsystem \\
\hline Release $(\Omega)$ & Dam removal & $\begin{array}{l}\text { Fish, sediment, } \\
\text { flow turmoil }\end{array}$ & $\begin{array}{l}\text { Alternate water, } \\
\text { power supply }\end{array}$ \\
\hline Renewal ( $\alpha)$ & $\begin{array}{l}\text { Natural flow } \\
\text { regime }\end{array}$ & $\begin{array}{l}\text { Ecological } \\
\text { dynamics } \\
\text { reordered }\end{array}$ & $\begin{array}{l}\text { Access to river, } \\
\text { fish, recreation }\end{array}$ \\
\hline $\begin{array}{l}\text { Rapid growth } \\
(r)\end{array}$ & $\begin{array}{l}\text { Riparian } \\
\text { ecosystem } \\
\text { services }\end{array}$ & $\begin{array}{l}\text { Riparian } \\
\text { corridor } \\
\text { reestablished }\end{array}$ & $\begin{array}{l}\text { Cultural } \\
\text { ecosystem values }\end{array}$ \\
\hline $\begin{array}{l}\text { Conservation } \\
(K)\end{array}$ & $\begin{array}{l}\text { Potential new } \\
\text { traps }\end{array}$ & $\begin{array}{l}\text { Accumulation, } \\
\text { variability }\end{array}$ & $\begin{array}{l}\text { Recreation } \\
\text { dominance }\end{array}$ \\
\hline
\end{tabular}

When a system is strongly connected, it is more resilient to external variability. The more rigid a system becomes, the more vulnerable it becomes. In institutional terms, older, more structured and hierarchical organizations, e.g., large federal agencies like the Bureau of Reclamation, are particularly prone to rigidity, making them even more prone to crisis and reorganization. A dam is perhaps the most apt metaphor to express this concept; dams become less stable over time and threaten to, literally, collapse. By decreasing the resilience of a river SES, dams also make the system more vulnerable to other disturbances such as climate change and growing water demand (Millar et al. 2007). However, the movement to decommission dams represents a way to remove an outdated and rigid technology in order to eliminate these points of rigidity from the social-ecological systems that they have altered. 
Fig. 2. Map of the Elwha Watershed and Olympic National Park.

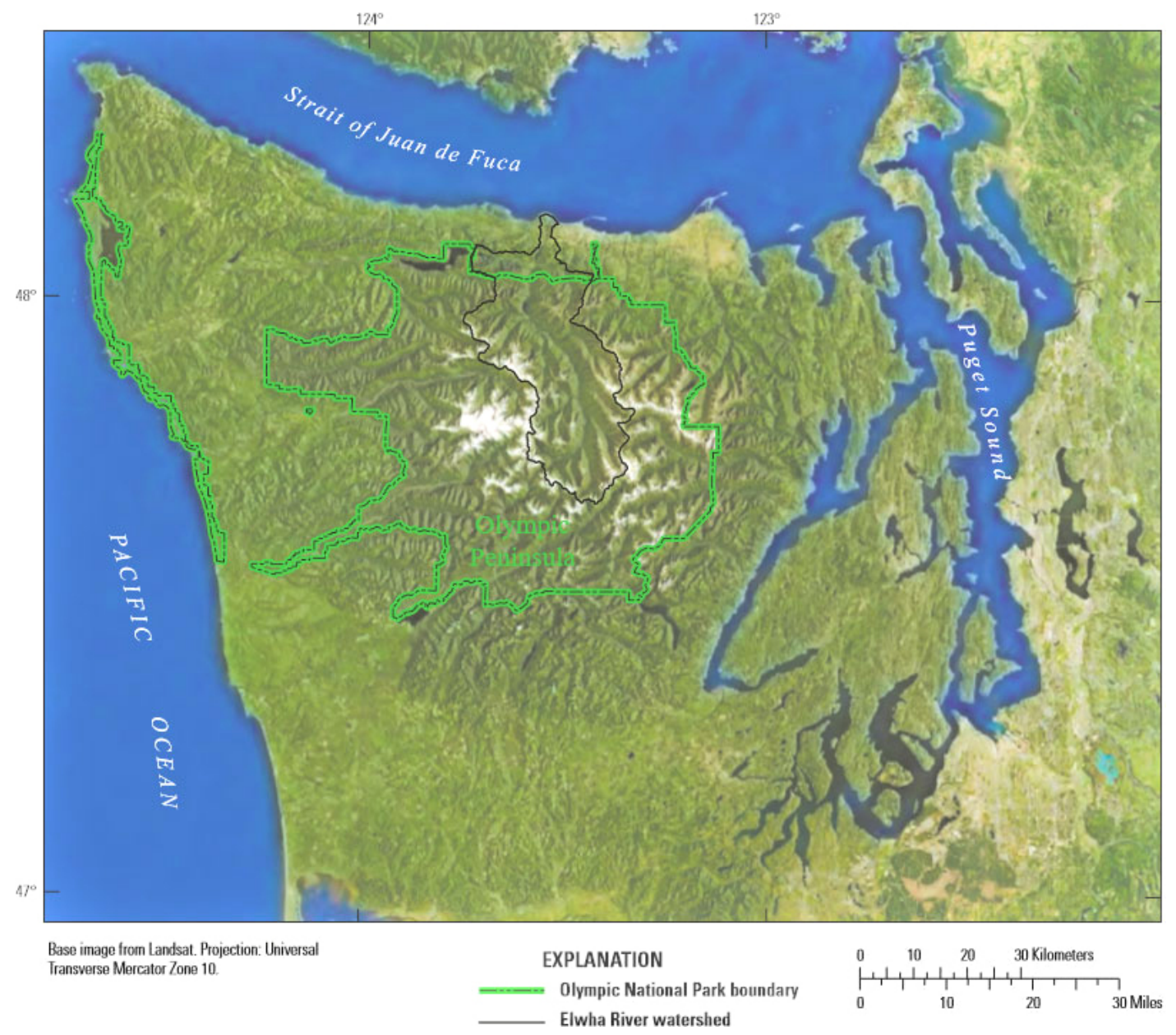

\section{METHODS}

We use the adaptive-cycle framework to examine both the evolution and decommissioning of the Elwha and Glines Canyon Dams on the Elwha River. To apply the framework, we assess the evolution of the decommissioning process in light of multiple adaptive-cycle phases to better understand how the process began, how it progressed, how the removal of the two dams represents a decrease in systemic rigidity, and how it improved resilience of the regional river SES both in the short term through restoration of salmon habitat and in the long term with eventual redistribution of sediment. This paper reviews scientific literature and uses secondary sources such as newspaper reports, informative records kept by the Lower Elwha Klallam Tribe, conservation organizations, state and federal agencies, and semistructured in-person and telephone interviews with a spokesperson for Olympic National Park and a representative of the Lower Elwha Klallam Tribe's Natural Resources Department. Although definitive conclusions cannot be drawn through this methodology given our small sample size, these interviews served as supplementary sources to build upon the findings from our archival research.

\section{Study area}

As the largest dam removal project in the history of the United States (Duda et al. 2008), the case of the Elwha established a precedent in the evolution of river management practices. The state of the Elwha River is inextricably linked with the Lower Elwha Klallam Tribe, a people who have relied upon the river and the various species of salmon that inhabit it for hundreds of years (Klallam interview 2014). For the Lower Elwha Klallam Tribe, who are also known as "Salmon People," salmon and water are central to the tribe's very identity, integral to ceremonies, culture, values, and diet into the present day (Klallam interview 2014). In 1855 , the Klallam (in addition to the Chemakum and Skokomish) signed the Treaty of Point No Point with the United States government, which reserved the right for the tribes to continue to take fish "at all usual and accustomed grounds and stations," but the construction of the Elwha and Glines Canyon Dams severely disrupted this right (Guarino 2013). Before the dams were constructed, they were able to catch, eat, and sell salmon yearround (Klallam Interview 2014).

In the late 1800s, Port Angeles in northwestern Washington began to grow and develop as homesteaders arrived to settle in the area, with many settled in traditional Klallam territory (Guarino 2013). 
In order to support this increased growth and economic activity, planners began looking for ways to expand the generation of electricity (National Park Service 2013a). Soon afterward, the Olympic Power Company began construction of the Elwha dam in 1910, which stood 31 meters high when completed in 1913 (McCully 2013). Construction of Glines Canyon dam began in 1925 and was completed in 1927; the Glines Canyon dam is 70 meters high. Despite a law passed in 1880 requiring water infrastructure to allow for the passage of fish, neither dam included any such infrastructure (NPS interview 2013). Olympic National Park was not established until 1937, and at the time of construction of the dams, the Lower Elwha Klallam Tribe did not have any political representation or the legal rights of American citizens. Despite this, the tribe protested the construction of the dams, which inundated a traditional village that was the tribe's Creation Site, and called for their removal from the very beginning (Guarino 2013).

An important note to make is that the Federal Power Commission (FPC), the organization that granted operating licenses to dams, was not created until 1920 when the Federal Power Act was passed in Congress (NPS interview 2013). Therefore, the Elwha Dam was not required to obtain any kind of official license to operate. The Glines Canyon Hydroelectric Project was constructed after the Elwha Dam, and in 1926, the FPC granted the Glines Canyon dam a 50-year license to produce hydroelectricity (National Park Service 2013a). In 1968 the owner of the two dams, the Crown Zellerbach Corporation (a large paper manufacturing firm) filed for a license for the first time for the Elwha Dam in addition to an application to relicense the Glines Canyon Dam. Because of the interconnectivity of the two dams, the Federal Energy Regulatory Commission (FERC) combined their license proceedings to better assess the cumulative impacts of both dams (Winter and Crain 2008). The relicensing proceedings played a key role in the eventual removal of the two dams because the original legislation did not address the issue of relicensing dams located within national parks. This represents a cross-scale institutional disturbance in the sense that it occurred external to the river SES.

By the time the relicensing process began, society's views about their surrounding environment had changed significantly since when the dams were first constructed (NPS interview 2013). Olympic National Park is a World Heritage Site and Biosphere Reserve (see Fig. 2) which brought more attention to how construction of the two dams had negatively impacted populations of salmon within the park (Brenkman et al. 2012). Salmon, including chinook (Oncorhynchus tshawytscha), coho $(O$. kisutch), pink (O. gorbuscha), chum (O. keta), and sockeye (O. nerka), and steelhead (O. mykiss) had all but disappeared because they lost access to approximately $95 \%$ of the watershed due to the construction of the dams.

The Klallam Tribe was key to spearheading the first steps toward decommissioning (NPS interview 2013). By time the relicensing process began, the tribe had become politically active. Although the tribe had opposed the dams since their original construction for cultural and spiritual reasons, safety was their main concern when the dam was due for relicensing in the 1970s. They commissioned a study on the dams to test their ability to withstand earthquakes; because of the location of the Lower Elwha Klallam reservation at the delta of the river, the failure of the dams and flooding of the reservoirs could have had disastrous consequences for them (Klallam interview 2014). The results showed not only that the dams were not up to code to withstand earthquakes, but also brought attention to their lack of fish passage. The tribe, funded by the Bureau of Indian Affairs, began conducting further impact studies that found that purchasing electricity from the Bonneville Dam on the Columbia Gorge was more economical than renovating the dam (Meyer et al. 1995). This was the first time that the removal of the dams was presented as a legitimate possibility (Klallam interview 2014). After a period of relatively stable operating conditions, relicensing became the institutional threshold that set in motion several adaptive responses including empowerment of the tribe, federal regulatory action, and advocacy-building by local nongovernmental interests.

In 1976, another key actor became involved in the relicensing process: the Secretary of the Interior was granted intervener status, which meant that the federal government would have a larger voice in the question of whether the dam would be licensed again without fish passage or any modifications to benefit the environment. Environmental groups had also begun to take notice of the degradation of the Elwha ecosystem and partnered with the Lower Elwha Klallam Tribe, mainly concerning the large decrease in salmon populations and lack of fish passage. In May of 1986, the Seattle Audubon Society, Friends of the Earth, Olympic Park Associates, and the Sierra Club publicly called for the decommissioning of the Elwha and Glines Canyon Dams. Six months later, these organizations were all granted intervener status in the relicensing process, in addition to the Lower Elwha Klallam Tribe and the NOAA National Marine Fisheries Service.

This began a period of intense research, a process of assembling resources as part of the adaptive-cycle $k$ (conservation) phase. FERC was involved in the Environmental Impact Statements (EIS) in order to explore the possibilities for decommissioning (NPS interview 2013). The first EIS focused on initial questions such as whether or not the ecosystem could be restored without taking the dams down, what type of fish passage might be appropriate, and what kind of fish passage would also allow the young salmon fry to travel safely downriver to the ocean (National Park Service 1996). However, the Pacific Fishery Management Council concluded that only dam removal could restore fish populations and diversity to appropriate and sustainable levels (National Park Service 2013a). Consequently, the second EIS addressed how to actually decommission the dams without causing ecological harm and further endangering salmon populations, followed by an intense period of legal negotiations (NPS interview 2013). Following these negotiations, all stakeholders reached an agreement. The corporation that owned the dams agreed to be paid for their losses over a period of 50 years, and signed over the dams to the United States Government under the Elwha River Ecosystem and Fisheries Restoration Act of 1992.

Congress passed the Elwha River Ecosystem and Fisheries Restoration Act, mandating the decommissioning of both dams and the "full restoration of the Elwha River ecosystem and native anadromous fisheries" (H.R. 4844). The Act is a negotiated settlement that met the needs of all parties involved. It enabled stakeholders to avoid prolonged conflict and costly litigation. It 
Fig. 3. The adaptive cycle of the Elwha.

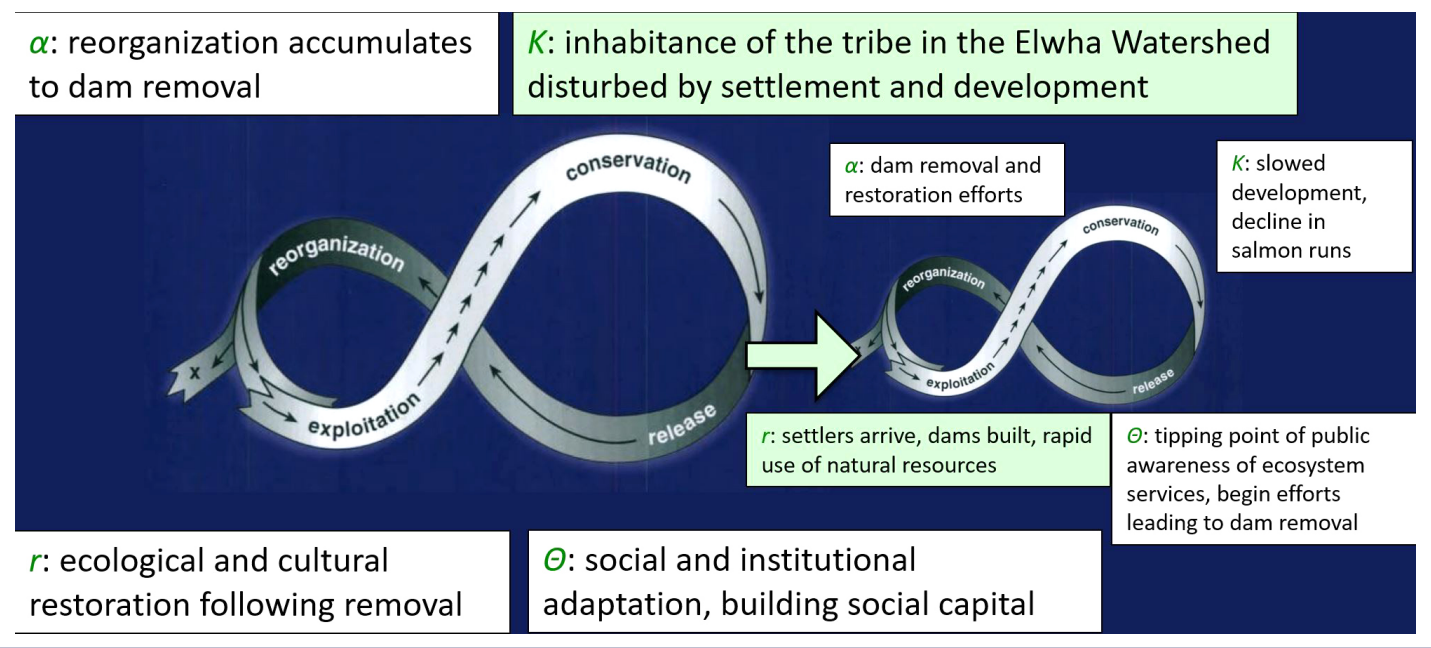

addresses a wide variety of stakeholder needs, including the replacement of power for the paper mill, monetary compensation for the dam owners, government guaranteed flood protection for downstream communities, and water quality protection for drinking water and septic systems. However, despite the eventual success of a negotiated settlement, the idea of removing the dams was nevertheless subject to public controversy. Locally, people were concerned about the impact on the economy and loss of power from the dams (Mapes 2011). There were also issues of civic pride, because the two dams were an integral part of the development of Port Angeles and many residents had personal or family history in connection to the dams. To lessen public concern, the tribe and various environmental groups utilized public education to help communities understand the various aspects of the project (Duda et al. 2008; Klallam interview 2014).

The decommissioning process began on 17 September 2011 when the Lower Elwha Klallam Tribe held a dam removal ceremony (Guarino 2013). Despite some continued skepticism and resistance, local communities and interested parties around the world were able to see the difference mere months after the dams had been removed; in August and September 2011 following the dams' removal, chinook salmon returned upstream to spawn where they had not been able to for 100 years (NPS Interview 2013). The Lower Elwha Klallam Tribe regarded the removal of the two dams as the restoration of their traditional way of life. They have begun the process of removing the hatcheries that they developed before the dam removals. The tribe has also pledged to continue to fight for the protection of salmon and traditional waterways (Columbia River Inter-Tribal Fish Commission 2013), and are now known internationally for their stream restoration crews, which have worked on the Elwha and are also sent to other watersheds around the country for their skills, such as engineering natural log jams for salmon habitat (Klallam interview 2014).

\section{RESULTS OF APPLYING THE ADAPTIVE-CYCLE FRAMEWORK}

The adaptive cycle may be conceived of at varying scales of complexity (see Fig. 3). Many stakeholder perspectives influence the phases of the cycle, and by applying the case of the two dam removals on the Elwha back to the concepts presented in Panarchy, it becomes apparent that two cycles were occurring simultaneously throughout the process of removing the Elwha and Glines Canyon Dams. This is primarily because among stakeholder perspectives, there are two distinctly different starting points of the cycle. Cycle 1 begins first because the indigenous people of the region had been integrated into the system for hundreds of years prior to European settlement. Cycle 2 begins when populations of settlers arrived to the Elwha watershed and adjoining region. Both stakeholder groups experienced the same chain of events that led to the eventual removal of the Elwha and Glines Canyon Dams; however, there is a time lag between their starting points. The first cycle's sequence is $K, \Omega, \alpha$, and $r$, and the second cycle's sequence is $r, K, \Omega$, and $\alpha$.

At the beginning of the first cycle in the conservation phase (represented in green in Fig. 3), the Lower Elwha Klallam Tribe was maintaining a somewhat stable relationship with their environment until the influx of settlers caused a disturbance to the relative balance the system had established (see Fig. 3). For the tribe, this disturbance challenged their ability to maintain their traditional way of life; ultimately, the construction of the dams, loss of salmon populations, and the tribe's lack of political influence pushed the system into the release phase. Again, in this phase, a disturbance exceeds the adaptive capacity of a system to cope. Although the initial disturbances caused by the development of the region may have been sudden, the effects of the disturbances continued throughout the next century. During this time, the tribe began to adapt institutionally and socially to the changes the system experienced; they formed a tribal council and gained political representation, becoming more interconnected again following a period of weakened connections. As their adaptive capacity increased with their social capital, the tribe was able to strengthen their demands for dam removal.

For the second cycle, the rapid growth phase of the adaptive cycle is represented by the influx of new inhabitants to the Elwha watershed, the beginning of Cycle 2. A period of rapid growth and the exploitation of available resources followed their arrival to the region; the system was not yet very interconnected, 
particularly when it came to relations between the indigenous people and the new settlers, and the growth occurred over a relatively short period of time. The construction of the dams is part of this initial period of growth. The next phase, conservation, consisted of a slower rate of growth that eventually led to the development of the region as we know it today. Although development continued, it did not occur as quickly as it did following initial colonization and construction of the dams and paper mill that fueled industrialization in Port Angeles. Throughout the decades following the construction of the dams, the system became more stable and accumulated potential in the forms of economic growth; cultural and ethical values become more equitable and inclusive, and the awareness and appreciation of the ecosystem services provided by the watershed increased. Although economic values were often contrary to cultural and environmental values, the damage being inflicted upon salmon populations, the cultural integrity of the Lower Elwha Klallam Tribe, and the ecological health of the river ultimately generated enough concern to create a tipping point of tribal action and public awareness that moved the adaptive cycle into the release phase.

At the point where stakeholders began calling for the removal of the two dams, the cumulative disturbances caused by the dams exceeded the system's capacity to adapt. According to Gunderson and Holling (2002) the back loop of the infinite loop model is the time of greatest potential for creating change in a system. For the Lower Elwha Klallam Tribe, this was when all of their reorganization efforts culminated into spearheading the final removal of the two dams, in conjunction with the efforts of other stakeholders. The dams represented points of rigidity that had to be removed in order to restore the system to a state of equilibrium where the values of all stakeholders are as equitably represented as possible; the inevitable finite lifetime of the dams created an economic incentive to enable that to happen. The Elwha River Ecosystem and Fisheries Restoration Act of 1992 is the product of this outcome. The renewal phase of a new cycle begins when their cumulative efforts result in the removal of the two dams.

The renewal phase of the cycle comprises the period when the dams were physically being removed, which continued until September of 2014, and the period of restoration that followed. Although scientific studies and data collection had begun years before the dams were removed, there was still scientific uncertainty surrounding the process of restoration because no such project had ever been undertaken before (Duda et al. 2008, National Park Service 2013b). However, this uncertainty led to innovative ideas, system reorganization, and the beginning of a new cycle in which a previously degraded ecosystem could begin the rapid growth phase of the cycle in order to regenerate, as shown by the rapid regeneration of the salmon population.

The organizational structure of the removal process was important to the success of the negotiations and ultimate project completion. Stakeholders represented different, but ultimately coalescing, interests and communicated among each other to find common ground, enabling successful collective action via a democratic process and effective communication between stakeholders without resorting to litigation (Brinkerhoff 2002). Another organizational aspect of the process of removal that contributed to its success is that the systemic change was initiated by the stakeholders operating at a lower political scale; concerned citizens, environmentalists, and tribal members tipped the higher scale of authority to initiate the process before the federal government became involved (Walker and Salt 2012). Successful negotiations of this scale are notable and somewhat rare accomplishments; it was reported (NPS interview 2013) that the multilevel organizational approach of the negotiations for the case of the Elwha could be applied as a model for future cases involving stakeholder collaboration. Despite multiple interests (that only partially overlapped among stakeholders early on), common ground was established quickly.

\section{DISCUSSION}

Public awareness and social movements are increasingly taking on board the concept of ecosystem services (Alexander et al. 2016) and emerging governance systems that accept demands and perspectives that historically have been marginalized (Pahl-Wostl et al. 2013). The decommissioning of the Elwha and Glines Canyon Dams represents an important precedent for progressive water management and the evolution of the perception of dams as a method of achieving social-ecological resilience. This case exemplifies how challenges to dam removal, such as a lack of data and scientific knowledge, dissent among stakeholders, and economic barriers can be successfully overcome. This case also demonstrates how differences in how the adaptive cycle is perceived by marginalized communities, in this case, Native Nations, and other communities can be successfully reconciled, and ultimately aligned through collective reorganization.

In the case of the Elwha, although the dams originally enabled the development of Port Angeles and provided various socialecological benefits to the surrounding region, the cultural and environmental benefits of removing them ultimately outweighed the costs. A tipping point, or threshold, occurred with an accumulation of collective knowledge of the potential benefits of removing the dams and the costs that renovating them would have incurred. In fact, the economic costs to dam removal ended up being less severe than many feared (NPS Interview 2013). The project provided for many innovative economic alternatives such as an increase in tourism and recreational opportunities in a more pristine national park (Meyer et al. 1995). The Elwha watershed, in part because of the protection it receives within Olympic National Park (Klallam interview, 2014) has the potential to be one of the most successful restoration projects of anadromous fish species and their habitat to date (McHenry and Pess 2008); the salmon runs in the region are expected to be restored to predam runs that were documented to be 400,000 salmon plus steelhead per year (Crane 2011, National Park Service 2013b).

Ultimately, the removal of the Elwha dams was facilitated by the FERC relicensing process that began in 1973 when the original 50 -year permit issued by the Federal Power Commission expired (Amos 2014). When the dams failed a safety inspection shortly afterward, it became clear that it was more economically viable to purchase electricity from the Bonneville Dam on the Columbia River than it would have been to renovate the Elwha and Glines Canyon dams, which opened up decommissioning for consideration in the first place (Amos 2014).

Focusing on increasing the resilience of river and riparian ecosystems provides a strategy for navigating the complexities of SESs in an uncertain future (Cosens and Fremier 2014). Social 
engagement is integral to resilient river governance (Cosens and Williams 2012). As demonstrated by the case of the Elwha, social engagement such as successful compromise and negotiation will be crucial to the future of successful riparian restoration projects. Essential elements of this process included constructive communication among stakeholders, reconciliation of differing perceptions of risk, and the collective creation of legislation that addresses the majority of stakeholder needs, including monetary needs (Moser and Ekstrom 2010). Dam removal projects in the future may implement similar elements of adaptive management that increase knowledge and coordination across multilevel governance structures (Chaffin et al. 2014).

\section{CONCLUSIONS}

In this paper we adapt and apply seminal concepts from the adaptive cycle framework and cultural ecosystem services, particularly for Native Nations, and use these to assess the unfolding case of decommissioning and restoration on the Elwha River in northwest Washington State. Our assessment indicates scalar and temporal alignment of two adaptive cycles. The Elwha case represents an illustrative and increasingly well-documented example of dam removal, in which stakeholder-based collaborative governance incorporated knowledge coproduction and regulatory maneuvering to successfully overcome obstacles inherent in both dam decommissioning and subsequent restoration. We consider this to be an important step in the evolution of river management practices.

The importance of the goods and ecosystem services that rivers provide for us cannot be understated; potable drinking water, the generation of electricity, irrigation for food production, and recreational and cultural values are all indispensable components of social-ecological systems that are being threatened by dams, widespread riparian degradation, and climate change. Decommissioning dams provides an option for stakeholders to engage in a comprehensive restoration project that may strengthen the resilience of a given SES to better absorb the environmental disturbances and changes that we face in the world today, such as climate induced changes to the natural flow regime.

Environmental disturbances to river and riparian ecosystems and the consequential effects on SES that rely upon them have exceeded the system's ability to absorb those disturbances. Dam decommissioning is gradually becoming a more accepted method of river restoration leading to ecosystem renewal and better human quality of life. In the face of increasingly degraded riparian ecosystems and aging dam structures around the world, dam removal is likely to become more politically feasible.

Responses to this article can be read online at: http://www.ecologyandsociety.org/issues/responses. php/9928

\footnotetext{
Acknowledgments:

We would like to thank the ex-official spokesperson for Olympic National Park and the Lower Elwha Klallam Tribe Natural Resources Department for all their assistance. Partial support was provided by a Faculty Exploratory Research Grant from the
}

University of Arizona's Institute of the Environment, National Science Foundation (NSF) Grant No. DEB-1010495, as well as Inter-American Institute for Global Change Research Projects CRN3056 (supported by NSF Grant No. GEO-1128040) and SGPCRA005 (supported by NSF Grant No. GEO-1138881).

\section{LITERATURE CITED}

Alexander, S., J. Aronson, W. Oliver, and D. Lamb. 2016. The relationship between ecological restoration and the ecosystem services concept. Ecology and Society 21(1):34. http://dx.doi. org/10.5751/ES-08288-210134

Amos, A. L. 2014. Dam removal and hydropower production in the United States-ushering in a new era. Journal of Environmental Law and Litigation 29(1).

Brenkman, S. J., J. J. Duda, C. E. Torgersen, E. Welty, G. R. Pess, R. Peters, and M. L. McHenry. 2012. A riverscape perspective of Pacific salmonids and aquatic habitats prior to large-scale dam removal in the Elwha River, Washington, USA. Fisheries Management and Ecology 19(1):36-53. http://dx.doi.org/10.1111/ j.1365-2400.2011.00815.X

Brinkerhoff, J. M. 2002. Global public policy, partnership, and the case of the world commission on dams. Public Administration Review 62(3):324-336. http://dx.doi.org/10.1111/1540-6210.00182

Chaffin, B. C., H. Gosnell, and B. A. Cosens. 2014. A decade of adaptive governance scholarship: synthesis and future directions. Ecology and Society 19(3):56. http://dx.doi.org/10.5751/ ES-06824-190356

Columbia River Inter-Tribal Fish Commission. 2013. We are all Salmon People. Columbia River Inter-Tribal Fish Commission, Portland, Oregon, USA. [online] URL: http://www.critfc.org/ salmon-culture/we-are-all-salmon-people/

Cosens, B., and A. Fremier. 2014. Assessing system resilience and ecosystem services in large river basins: a case study of the Columbia river basin. Idaho Law Review 51:91-125.

Cosens, B. A., and M. K. Williams. 2012. Resilience and water governance: adaptive governance in the Columbia River basin. Ecology and Society 17(4):3. http://dx.doi.org/10.5751/ES-04986-170403

Crane, J. 2011. Finding the river: an environmental history of the Elwha. Oregon State University Press, Corvallis, Oregon, USA.

Dallman, S., M. Ngo, P. Laris, and D. Thien. 2013. Political ecology of emotion and sacred space: the Winnemem Wintu struggles with California water policy. Emotion, Space and Society 6(1):33-43. http://dx.doi.org/10.1016/j.emospa.2011.10.006

Department of Interior. 2007. Record of decision: Colorado River interim guidelines for lower basin shortages and the coordinated operations for Lake Powell and Lake Mead. Department of the Interior, Washington, D.C., USA.

Doyle, M. W., J. M. Harbor, and E. H. Stanley. 2003. Toward policies and decision-making for dam removal. Environmental Management 31(4):0453-0465. http://dx.doi.org/10.1007/s00267-002-2819$\underline{\mathrm{Z}}$

Duda, J. J., J. E. Freilich, and E. G. Schreiner. 2008. Baseline studies in the Elwha River ecosystem prior to dam removal: 
introduction to the Special Issue. Northwest Science 82:1-12. http://dx.doi.org/10.3955/0029-344X-82.S.I.1

Fiege, M. 1999. Irrigated Eden: the making of an agricultural landscape in the American West. University of Washington Press, Seattle, Washington, USA.

Folke, C. 2016. Resilience (Republished). Ecology and Society 21 (4):44. https://doi.org/10.5751/ES-09088- 210444

Fox, C. A., F. J. Magilligan, and C. S. Sneddon. 2016. "You kill the dam, you are killing a part of me": dam removal and the environmental politics of river restoration. Geoforum 70:93-104. http://dx.doi.org/10.1016/j.geoforum.2016.02.013

Gimblett, H. R., C. A. Scott, and M. Hammersley. 2017. Dam removal on the Lower White Salmon River: rewilding, sacred spaces, and "outstandingly remarkable values." International Journal of Wilderness 23(2):34-40.

Guarino, J. 2013. Tribal advocacy and the art of dam removal: the Lower Elwha Klallam and the Elwha Dams. American Indian Law Journal II(I):114-145.

Gunderson, L. H., and C. S. Holling. 2002. Panarchy: understanding transformations in human and natural systems. Island, Washington, D.C., USA.

Harnish, R. A., R. Sharma, G. A. McMichael, R. B. Langshaw, and T. N. Pearsons. 2014. Effect of hydroelectric dam operations on the freshwater productivity of a Columbia River fall Chinook salmon population. Canadian Journal of Fisheries and Aquatic Sciences 71:602-615. http://dx.doi.org/10.1139/cjfas-2013-0276

Magilligan, F. J., C. S. Sneddon, and C. A. Fox. 2017. The social, historical, and institutional contingencies of dam removal. Environmental Management 59(6):982-994. http://dx.doi.org/10.1007/ s00267-017-0835-2

Mapes, L. 2011. Elwha: the grand experiment to tear down two dams and return an Olympic wilderness to its former glory. The Seattle Times, 21 September. [online] URL: http://seattletimes. com/flatpages/specialreports/elwha/

McCully, P. 2013. Dam decommissioning. International Rivers, Berkeley, California, USA. [online] URL: http://www. internationalrivers.org/dam-decommissioning

McHenry, M. L., and G. R. Pess. 2008. An overview of monitoring options for assessing the response of salmonids and their aquatic ecosystems in the Elwha River following dam removal. Northwest Science 82:29-47. http://dx.doi.org/10.3955/0029-344X-82.S.I.29

Meyer, P. A., R. Lichtkoppler, R. B. Hamilton, C. L. Borda, D. A. Harpman, and P. M. Engel. 1995. Elwha River restoration project: economic analysis. Final technical report. U.S. Bureau of Reclamation, National Park Service, Lower Elwha S'Klallam Tribe, Davis, California, USA. [online] URL: https://www.nps. gov/olym/learn/nature/upload/Economic $\% 20$ analysis.pdf

Millar, C. I., N. L. Stephenson, and S. L. Stephens. 2007. Climate change and forests of the future: managing in the face of uncertainty. Ecological Applications 17(8):2145-2151. [online] URL: http://dx.doi.org/10.1890/06-1715.1

Moser, S. C., and J. A. Ekstrom. 2010. A framework to diagnose barriers to climate change adaptation. Proceedings of the National
Academy of Sciences of the United States of America 107 (51):22026-22031. http://dx.doi.org/10.1073/pnas.1007887107

National Park Service. 1996. Final environmental impact statement: Elwha River ecosystem restoration implementation. U. S. Department of the Interior, Washington, D.C., USA. [online] URL: https://www.nps.gov/olym/learn/nature/loader.cfm?csModule= $\underline{\text { security/getfile \&PageID }=136253}$

National Park Service. 2013a. Timeline of the Elwha. U.S. Department of the Interior, Washington, D.C., USA. [online] URL: http://www.nps.gov/olym/historyculture/timeline-of-theelwha-through-1940.htm

National Park Service. 2013b. Elwha River Restoration. U.S. Department of the Interior, Washington, D.C., USA. [online] URL: https://www.nps.gov/olym/learn/nature/upload/Elwha-RiverRestoration-Brochure-2013 Final.pdf

Nilsson, C., and M. Svedmark. 2002. Basic principles and ecological consequences of changing water regimes: riparian plant communities. Environmental Management 30(4):468-480. http://dx.doi.org/10.1007/s00267-002-2735-2

Pahl-Wostl, C., A. Arthington, J. Bogardi, S. Bunn, H. Hoff, L. Lebel, E. Nikitina, M. Palmer, L. N. Poff, K. Richards, M. Schlüter, R. Schulze, A. St-Hilaire, R. Tharme, K. Tockner, and D. Tsegai. 2013. Environmental flows and water governance: managing sustainable water uses. Current Opinion in Environmental Sustainability 5(3-4):341-351. http://dx.doi. org/10.1016/j.cosust.2013.06.009

Pejchar, L., and K. Warner. 2001. A river might run through it again: criteria for consideration of dam removal and interim lessons from California. Environmental Management 28 (5):561-575. http://dx.doi.org/10.1007/s002670010244

Peters, D. P. C., B. T. Bestelmeyer, K. M. Havstad, A. Rango, S. R. Archer, A. C. Comrie, H. R. Gimblett, L. López-Hoffman, O. E. Sala, E. R. Vivoni, M. L. Brooks, J. Brown, H. C. Monger, J. H. Goldstein, G. S. Okin, and C. E. Tweedie. 2013. Desertification of rangelands. Pages 239-258 in R. A. Pielke and D. Niyogi. Climate vulnerability: understanding and addressing threats to essential resources. Elsevier, Academic Press, Cambridge, Massachusetts, USA. http://dx.doi.org/10.1016/B978-0-12-3847$\underline{03-4.00426-3}$

Poff, N. L., J. D. Allan M. B. Bain, J. R. Karr, K. L. Prestegaard, B. D. Richter, R. E. Sparks, and J. C. Stromberg. 1997. The natural flow regime. BioScience 47(11):769-784. http://dx.doi. org/10.2307/1313099

Richter, B. D., A. T. Warner, J. L Meyer, and K. Lutz. 2006. A collaborative and adaptive process for developing environmental flow recommendations. River Research and Applications 22 (3):297-318. http://dx.doi.org/10.1002/rra.892

Scott, C. A., S. Vicuña, I. Blanco-Gutiérrez, F. Meza, and C. Varela-Ortega. 2014. Irrigation efficiency and water-policy implications for river basin resilience. Hydrology and Earth System Sciences 18(4):1339-1348. http://dx.doi.org/10.5194/ hess-18-1339-2014

Stanley, E. H., and M. W. Doyle. 2003. Trading off: the ecological effects of dam removal. Frontiers in Ecology and the Environment 
1(1):15-22. http://dx.doi.org/10.1890/1540-9295(2003)001[0015: TOTEEO]2.0.CO;2

U.S. Congress. 1992. Elwha River Ecosystem and Fisheries Restoration Act. H.R. 4844. 102nd U.S. Congress, Washington, D.C., USA. [online] URL: https://www.nps.gov/olym/learn/ nature/upload/ElwhaAct.pdf

Walker, B., and D. Salt. 2012. Preparing for practice: the essence of resilience thinking. Pages 1-35 in B. Walker and D. Salt, editors. Resilience practice: building capacity to absorb disturbance and maintain function. Island, Washington, D.C., USA. http://dx.doi. org/10.5822/978-1-61091-231-0_1

Whitelaw, E., and E. Macmullan. 2002. A framework for estimating the costs and benefits of dam removal: sound costbenefit analyses of removing dams account for subsidies and externalities, for both the short and long run, and place the estimated costs and benefits in the appropriate economic context. BioScience 52(8):724-730. http://dx.doi.org/10.1641/0006-3568 (2002)052[0724:AFFETC]2.0.CO;2

Winter, B. D., and P. Crain. 2008. Making the case for ecosystem restoration by dam removal in the making the case for ecosystem restoration by dam removal in the Elwha River, Washington. Northwest Science82:13-28. https://doi.org/10.3955/0029-344X-82. S.I.13 http://dx.doi.org/10.3955/0029-344X-82.S.I.13

World Commission on Dams. 2000. Dams and development: a new framework for decision-making. Earthscan, London, UK. 